\title{
Article \\ Selective BuChE Inhibitory Activity, Chemical Composition, and Enantiomeric Content of the Essential Oil from Salvia leucantha Cav. Collected in Ecuador
}

\author{
Gabriela Villalta ${ }^{1}\left(\mathbb{D}\right.$, Melissa Salinas ${ }^{1}\left(\mathbb{D}\right.$, James Calva ${ }^{1}\left(\mathbb{D}\right.$, Nicole Bec $^{2} \mathbb{D}$, Christian Larroque $^{2}$, Giovanni Vidari $^{3}$ \\ and Chabaco Armijos $1, *$ (D)
}

1 Departamento de Química, Universidad Técnica Particular de Loja, 1101608 Loja, Ecuador; gcvillalta1@utpl.edu.ec (G.V.); masalinas4@utpl.edu.ec (M.S.); jwcalva@utpl.edu.ec (J.C.)

2 Institute for Regenerative Medicine and Biotherapy (IRMB), Université de Montpellier, INSERM, CHU Montpellier, 34295 Montpellier, France; nicole.bec@inserm.fr (N.B.); cjlarroque@gmail.com (C.L.)

3 Medical Analysis Department, Faculty of Science, Tishk International University, Erbil 44001, Iraq; vidari@unipv.it

* Correspondence: cparmijos@utpl.edu.ec

Citation: Villalta, G.; Salinas, M.; Calva, J.; Bec, N.; Larroque, C.; Vidari, G.; Armijos, C. Selective BuChE Inhibitory Activity, Chemical Composition, and Enantiomeric Content of the Essential Oil from Salvia leucantha Cav. Collected in Ecuador. Plants 2021, 10, 1169. https://doi.org/10.3390/ plants10061169

Academic Editors: Cecilia Cagliero, Patrizia Rubiolo and Barbara Sgorbini

Received: 18 May 2021

Accepted: 3 June 2021

Published: 9 June 2021

Publisher's Note: MDPI stays neutral with regard to jurisdictional claims in published maps and institutional affiliations.

Copyright: (c) 2021 by the authors. Licensee MDPI, Basel, Switzerland. This article is an open access article distributed under the terms and conditions of the Creative Commons Attribution (CC BY) license (https:/ / creativecommons.org/licenses/by/ $4.0 /)$.

\begin{abstract}
The essential oil (EO) of Salvia leucantha Cav. was isolated by steam distillation of the aerial parts collected in the South of Ecuador. Its physical properties were evaluated and the chemical composition of the oil was determined by GC-MS and GC-FID analyses using two chromatographic columns, DB-5ms and HP-INNOWax. Six major compounds were identified, namely, the sesquiterpenes 6.9-guaiadiene $(19.14 \%),(E)$-caryophyllene $(16.80 \%)$, germacrene D $(10.22 \%)$, (E)- $\beta$-farnesene $(10.00 \%)$, and bicyclogermacrene $(7.52 \%)$, and the monoterpenoid bornyl acetate $(14.74 \%)$. Furthermore, four pairs of enantiomers were determined by enantioselective GC-MS of the essential oil. (-)-germacrene D and (+)- $\alpha$-pinene showed the highest enantiomeric excess (ee\%). In an in vitro assay, the essential oil demonstrated an interesting inhibitory activity of the enzyme butyrylcholinesterase $(\mathrm{BuChE})$, with an $\mathrm{IC}_{50}=32.60 \mu \mathrm{g} / \mathrm{mL}$, which is the highest determined for a Salvia species. In contrast, the oil was weakly active against acetylcholinesterase (AChE) with an $\mathrm{IC}_{50}>250 \mu \mathrm{g} / \mathrm{mL}$.
\end{abstract}

Keywords: Salvia leucantha; essential oil; enantiomer distribution; GC-MS; GC-FID; BuChE inhibitory activity

\section{Introduction}

The family Lamiaceae comprises about 235 genera and approximately 7170 identified species [1]. Salvia, that is the largest genus in the family, is estimated to include about 900 species distributed worldwide [2]. In Ecuador, the family Lamiaceae comprises about 27 genera and 219 species that grow especially in Andean forests, badlands, and dry inter-Andean valleys [3]. Several Lamiaceae have a high pharmacological value, for the production of a wide range of secondary metabolites with antibacterial, antioxidant, antiinflammatory, antimicrobial, antiviral, and anticancer properties [4].

Salvia leucantha Cav. (Mexican bush sage, velvet sage) is a plant native to Mexico that is now distributed worldwide, including across the entire American continent [5]. It is an herbaceous shrub that can reach up to $1.20 \mathrm{~m}$ in height; the lanceolate leaf blades are $10-20 \mathrm{~cm}$ long and are grayish-green with a velvety texture. It has a purple chalice and purple or white corolla that are covered by thin, velvety hairs. The plant is used in traditional medicine as a remedy to relieve cough, chest, lung, and stomach pains, as well as a garden plant $[6,7]$.

The plant has a pleasant smell due to the presence of a fragrant volatile fraction. According to a few studies carried out in Asia and South America on the chemical composition of the essential oil (EO) from $S$. leucantha, sesquiterpene hydrocarbons have been 
identified as the predominant components [8]. Moreover, in vitro studies of the EO have shown various properties such as antioxidant, antimicrobial, antispasmodic, as well as digestive and neuroprotective effects [9].

On a general note, thanks to their odorant and biological properties, such as antimicrobial, antioxidant, anti-inflammatory, antiviral, antimutagenic, and anticancer ones [10,11], several EOs have applications not only in fragrance industries and food flavorings, but also in medical and clinical microbiology, pharmaceutical botany, food preservation, and others $[12,13]$. In this context, considering the various pharmaceutical properties of the components, it is important to also test EO's activity on less traditional pharmacological targets or biological systems, such as the cholinesterase (ChE) enzymes, acetylcholinesterase (AChE) and butyrylcholinesterase (BuChE). In fact, these enzymes are actively involved in studies aimed at the treatment of neurodegenerative diseases such as Alzheimer's (AD) [14], neuromuscular disorders such as Myasthenia gravis (MG), and eye pathologies such as glaucoma. Patients treated with $\mathrm{ChE}$ inhibitors seem to experience improvements in their cognitive functions; however, the features of the two ChE inhibitors differ considerably [15].

We were interested in comparing the $\mathrm{EO}$ isolated from aerial parts of S. leucantha collected in Ecuador with the essential oils from samples of the plant collected in other countries. In fact, different chemical compositions may indicate the existence of genotypes. Equally important to us was determining, for the first time, the enantiomeric composition and the in vitro $\mathrm{AChE}$ and BuChE inhibitory activities of the EO.

\section{Results and Discussion}

\subsection{Physical Properties of the EO}

The steam-distilled EO from aerial parts of S. leucantha presented a pale-yellow color and a pleasant smell. The average yield of three distillations was $0.03 \pm 0.01 \%$. The mean relative density and refractive index of the oil were $0.94 \pm 0.01 \mathrm{~g} / \mathrm{mL}$ and $1.49 \pm 0.01$, respectively.

\subsection{Chemical Composition of the EO}

Forty-two compounds were identified in the EO by using GC-MS and GC-FID analyses. When using a non-polar DB-5ms column, $99.13 \%$ of the components present in the EO were identified, while $98.05 \%$ of the EO components were identified when using a polar HPINNOWax column. The analysis on DB-5ms showed that $S$. leucantha EO consists mostly of sesquiterpene hydrocarbons $(71.49 \%)$, oxygenated monoterpenes $(15.12 \%)$, monoterpene hydrocarbons $(9.48 \%)$, oxygenated sesquiterpenes $(1.70 \%)$, and other compounds $(1.34 \%)$. The most abundant identified compounds were 6,9-guaiadiene (19.14\%), (E)-caryophyllene $(16.80 \%)$, bornyl acetate $(14.74 \%)$, germacrene $\mathrm{D}(10.22 \%),(E)-\beta$-farnesene $(10.00 \%)$, and bicyclogermacrene $(7.52 \%)$ (Table 1$)$. Comparable results were obtained for the analysis performed on the polar column (Table 1). The percentage content of each compound reported in Table 1 is the mean of three analyses. 
Table 1. Chemical composition of Salvia leucantha Cav. EO.

\begin{tabular}{|c|c|c|c|c|c|c|c|c|}
\hline \multirow{2}{*}{ Component } & \multicolumn{4}{|c|}{ DB-5ms } & \multicolumn{4}{|c|}{ HP-INNOWax } \\
\hline & LRI $^{a}$ & LRI $^{b}[16]$ & $\%^{c}$ & S.D ${ }^{d}$ & LRI $^{a}$ & LRI $^{b}$ & $\%^{c}$ & S.D ${ }^{d}$ \\
\hline$\alpha$-Pinene & 942 & 932 & 3.31 & 0.68 & 1055 & 1066 [17] & 3.70 & 0.31 \\
\hline Camphene & 956 & 946 & 3.03 & 0.55 & 1079 & 1084 [17] & 3.33 & 0.27 \\
\hline Sabinene & 975 & 969 & 0.48 & 0.07 & 1120 & 1117 [18] & 0.51 & 0.06 \\
\hline$\beta$-Pinene & 979 & 974 & 2.01 & 0.50 & 1108 & $1104[18]$ & 2.15 & 0.17 \\
\hline Myrcene & 990 & 988 & 0.17 & 0.02 & - & - & - & - \\
\hline Limonene & 1028 & 1024 & 0.35 & 0.07 & 1199 & 1199 [17] & 0.29 & 0.03 \\
\hline$\gamma$-Terpinene & 1056 & 1054 & 0.13 & 0.02 & - & - & - & - \\
\hline$\alpha$-Phellandrene & - & - & - & - & 1162 & 1160 [19] & 0.15 & 0.01 \\
\hline $\begin{array}{l}\text { 3-Methyl-3-butenyl, } \\
\text { 3-methyl- butanoate }\end{array}$ & 1112 & 1112 & 0.12 & 0.00 & - & - $12=1$ & - & - \\
\hline Borneol & 1171 & 1165 & 0.14 & 0.04 & - & - & - & - \\
\hline Terpinene-4-ol & 1178 & 1174 & 0.12 & 0.04 & - & - & - & - \\
\hline Bornyl acetate & 1286 & 1284 & 14.74 & 0.31 & 1577 & $1580[20]$ & 13.26 & 0.22 \\
\hline Humulene & - & - & - & - & 1658 & $1660[20]$ & 0.75 & 0.01 \\
\hline$\delta$-Elemene & 1333 & 1335 & 0.54 & 0.01 & 1466 & $1460[20]$ & 1.30 & 0.18 \\
\hline$\alpha$-Copaene & 1372 & 1374 & 0.36 & 0.01 & 1483 & 1493 [18] & 0.35 & 0.00 \\
\hline$\beta$-Bourbonene $e^{e}$ & 1379 & 1387 & 0.35 & 0.00 & 1509 & 1519 [21] & 0.36 & 0.01 \\
\hline$\beta$-Elemene & 1386 & 1389 & 0.42 & 0.01 & - & - & - & - \\
\hline (E)-Caryophyllene & 1418 & 1417 & 16.80 & 0.16 & 1588 & 1590 [20] & 17.56 & 0.20 \\
\hline$\beta$-Copaene & 1425 & 1430 & 0.14 & 0.01 & - & - & - & - \\
\hline Aromadendrene & 1433 & 1439 & 0.35 & 0.00 & 1613 & 1613 [22] & 1.74 & 0.01 \\
\hline 6,9-Guaiadiene & 1442 & 1442 & 19.14 & 0.29 & 1600 & 1617 [23] & 17.8 & 0.17 \\
\hline $\begin{array}{l}\text { Allo- } \\
\text { aromadendrene }\end{array}$ & 1447 & 1458 & 1.88 & 0.04 & 1633 & 1633 [17] & 0.64 & 0.01 \\
\hline (E)- $\beta$-Farnesene & 1455 & 1454 & 10.00 & 0.47 & 1670 & 1665 [24] & 9.11 & 0.16 \\
\hline Germacrene D & 1481 & 1480 & 10.22 & 0.11 & 1699 & $1700[20]$ & 12.5 & 0.20 \\
\hline $\begin{array}{l}\text { trans-Cadina-1(6).4- } \\
\text { diene }\end{array}$ & 1482 & 1475 & 0.53 & 0.00 & - & - & - & - \\
\hline$\beta$-Selinene & 1485 & 1489 & 0.29 & 0.16 & 1706 & 1708 [24] & 0.38 & 0.04 \\
\hline Bicyclogermacrene & 1494 & 1500 & 7.52 & 0.07 & 1724 & 1723 [17] & 6.23 & 0.04 \\
\hline n-Pentadecane & 1500 & 1500 & 0.16 & 0.01 & 1500 & $1500[25]$ & 0.26 & 0.01 \\
\hline$\gamma$-Cadinene & 1509 & 1513 & 1.07 & 0.02 & 1750 & 1750 [17] & 0.47 & 0.01 \\
\hline$\delta$-Amorphene & 1511 & 1511 & 1.31 & 0.05 & - & - & - & - \\
\hline Furopelargone A & 1527 & 1538 & 0.39 & 0.02 & - & - & - & - \\
\hline Germacrene B & 1553 & 1559 & 0.41 & 0.03 & 1815 & $1811[26]$ & 0.24 & 0.02 \\
\hline Spatulenol & 1573 & 1577 & 0.55 & 0.00 & 2118 & 2118 [17] & 1.90 & 0.07 \\
\hline Cubeban-11-ol e & 1577 & 1595 & 0.62 & 0.01 & - & - & - & - \\
\hline Cadinol & 1638 & 1638 & 0.14 & 0.00 & - & - & - & - \\
\hline Mint sulfide ${ }^{\mathrm{e}}$ & 1730 & 1740 & 0.29 & 0.06 & - & - & - & - \\
\hline Sclarene & 1977 & 1974 & 1.05 & 0.15 & - & - & - & - \\
\hline Caryophyllene oxide & - & - & - & - & 1967 & 1967 [17] & 0.87 & 0.01 \\
\hline$\alpha$-Cadinol & - & - & - & - & 2229 & $2220[21]$ & 0.22 & 0.01 \\
\hline trans- $\alpha$-Bergamotol & - & - & - & - & 2249 & $2247[23]$ & 1.98 & 0.19 \\
\hline \multicolumn{3}{|c|}{ Monoterpene hydrocarbons (\%) } & 9.48 & & & & 10.13 & \\
\hline \multicolumn{3}{|c|}{ Oxygenated monoterpenes $(\%)$} & 15.12 & & & & 13.26 & \\
\hline \multicolumn{3}{|c|}{ Sesquiterpene hydrocarbons (\%) } & 71.49 & & & & 69.69 & \\
\hline \multicolumn{3}{|c|}{ Oxygenated sesquiterpenes (\%) } & 1.70 & & & & 4.97 & \\
\hline \multicolumn{3}{|c|}{ Others $(\%)$} & 1.34 & & & & - & \\
\hline \multicolumn{3}{|c|}{ Total identified (\%) } & 99.13 & & & & 98.05 & \\
\hline
\end{tabular}

${ }^{\mathrm{a}}$ Linear retention index (LRI), calculated according to Van den Dool and Kratz [27]; ${ }^{\mathrm{b}}$ reference linear retention index; ${ }^{\mathrm{c}}$ content $(\%)$ as a mean of three determinations; ${ }^{\mathrm{d}}$ standard deviation; ${ }^{\mathrm{e}}$ identified tentatively.

The chemical profiles of the EO from S. leucantha collected in Southern Ecuador (Table 1), were compared with studies on samples from the plant collected in Asia and America. In these oils, sesquiterpenes and monoterpenes were reported as the major components. The EO from aerial parts including flowers of the plant collected in India, contained bornyl acetate $(23.9 \%)$, (E)-caryophyllene (13.9\%), germacrene D $(13.8 \%)$, and 
bicyclogermacrene (8.7\%) as major constituents [8], whereas the leaf EO was characterized by the presence of bornyl acetate $(27.8 \%)$ and $(E)$-caryophyllene $(10.7 \%)$ [28]. On the other hand, the EO from leaves of $S$. leucantha collected in Indonesia contained (E)-caryophyllene $(7.87 \%)$ and bicyclogermacrene $(5.13 \%)$ as the major components [9]. Bornyl acetate $(11.4 \%)$, (E)-caryophyllene (6.5\%), and 6,9-guaiadiene (4.9\%) were the major EO components from aerial parts of S. leucantha, collected in United States [29]. A study of the EO from flowers collected in Colombia reported the presence of $(E)-\beta$-farnesene $(10.7 \%)$, germacrene D $(10.6 \%),(E)$-caryophyllene $(10 \%)$, and bornyl acetate $(9.8 \%)$ [30]. Finally, a study of the EO from aerial parts (fresh leaves) of the plant collected in Venezuela, mentioned bornyl acetate $(24.1 \%),(E)$-caryophyllene $(14.1 \%)$, bicyclogermacrene $(8.9 \%)$, and germacrene D $(6.6 \%)$ as the major constituents [5].

Comparing the compositions of the EOs from the different samples of S. leucantha, it appears that they are characterized by the presence of high amounts of sesquiterpenoids. However, the presence of a high amount (about 19\%) of 6,9-guaiadiene is a special characteristic of the EO from aerial parts of the plant collected in Ecuador. In fact, significant amounts of this sesquiterpene have not been reported in the EOs of samples from India, Indonesia, Colombia and Venezuela, whereas the EO from S. leucantha aerial parts collected in USA contained less than 5\% 6,9-guaiadiene. By contrast, significant amounts of $(E)$ caryophyllene and monoterpene bornyl acetate occur in almost all the EOs of $S$. leucantha examined so far.

In conclusion, the chemical profiles of the EOs isolated from S. leucantha growing in different countries are similar; however, they are not identical, and thus characterize each oil. On the other hand, one must remember that the different percentages of the major constituents of the different EOs could depend on several factors such as origin, age, plant part, climate, place of growth, soil conditions, temperature, extraction methods and storage [31].

The biological activities shown by the main constituents of $S$. leucantha EO justify the potential use of the plant as a medicinal remedy [32]. (E)-caryophyllene has exhibited antiinflammatory, antidiabetic and hepatoprotective effects [33], antinociceptive activity [34] and relevant cytotoxicity against several types of cancer cells [35]. Germacrene D is involved in ecological interactions of plants with insects and other predators [36]; in addition, germacrene $\mathrm{D}$ has displayed anti-inflammatory properties [37]. (E)- $\beta$-Farnesene is currently used as a defense chemical against insects [38,39]; bicyclogermacrene showed cytotoxic activity [40] and a possible antiviral activity against SARS-CoV-2 [41]; finally, bornyl acetate exhibited antioxidant [42], anti-inflammatory $[43,44]$ and repellent effects against storage insects [45].

\subsection{Enantiomeric Analysis of the EO}

The enantiomeric composition of an EO is an important characteristic of the oil and an essential marker to determine the authenticity of a plant species [46]. Therefore, we submitted for the first time the EO from S. leucantha to an enantioselective analysis. Using the chiral column at our disposal we detected four pairs of enantiomers whose peaks were well separated at the base and could be quantified with accuracy. The linear retention indices, enantiomeric distribution and enantiomeric excess $(e e \%)$ of each pair are shown in Table 2. The order of elution of the enantiomers was determined by injection of enantiomerically pure standards. 
Table 2. Enantiomeric analysis of Salvia leucantha Cav. EO.

\begin{tabular}{|c|c|c|c|}
\hline Enantiomer & LRI $^{a}$ & $\begin{array}{c}\text { Enantiomeric } \\
\text { Distribution (\%) }\end{array}$ & $e e \%$ \\
\hline$(+)$ - $\alpha$-Pinene & 926 & 4.32 & \multirow{3}{*}{91.36} \\
\hline & & & \\
\hline$(-)$ - $\alpha$-Pinene & 932 & 95.68 & \\
\hline (+)-Sabinene & 973 & 29.98 & \multirow{3}{*}{40.04} \\
\hline & & & \\
\hline (-)-Sabinene & 975 & 70.02 & \\
\hline$(+)$-Aromadendrene & 1426 & 19.15 & \multirow{3}{*}{61.70} \\
\hline & & & \\
\hline$(-)$-Aromadendrene & 1440 & 80.85 & \\
\hline$(+)$-Germacrene D & 1475 & 1.65 & \multirow{3}{*}{96.70} \\
\hline & & & \\
\hline (-)-Germacrene D & 1489 & 98.35 & \\
\hline
\end{tabular}

a Linear retention index calculated on the chiral capillary column diethyl tertbuthysilyl- $\beta$-cyclodextrin; ${ }^{\mathrm{b}}$ enantiomeric excess.

$(-)$-Germacrene $\mathrm{D}$ and $(+)-\alpha-$ pinene exhibited a high enantiomeric excess, whereas $(-)$-aromadendrene was enantioenriched only moderately and the enantiomeric excess of $(-)$-sabinene was low.

The majority of the EO components detected by the GC-FID analysis (Table 1), including the most abundant ones, overlapped on our chiral column or appeared as a single peak. Of course, this finding did not necessarily indicate that they were enantiomerically pure, because peak coalescence might depend on the inadequate resolving power of the chiral column used. However, although the enantioselective analysis of the EO from S. leucantha cannot be considered definitive, these data are, however, significant and add further evidence that secondary metabolites often exist in plants as mixtures of stereoisomers.

\subsection{Cholinesterase ( $A C h E$ and $B u C h E$ ) Inhibitory Activity of the EO}

The enzymes AChE as well as BuChE are considered to be primary ChE regulators [47]; moreover, cholinesterase $(\mathrm{ChE})$ inhibition represents the most efficacious treatment approach for Alzheimer's disease (AD) to date. In a normal brain, AChE represents $80 \%$ of the activity, while BuChE represents the remaining 20\% [48]. In the brains of patients with Alzheimer's disease (AD) brain, BuChE activity rises, while AChE activity remains unchanged or declines. It has been demonstrated that the selective inhibition of BuChE not only increases the acetylcholine level significantly but also improves memory in elderly rats [49]. Therefore, $\mathrm{ChE}$ inhibitors, as well as selective $\mathrm{BuChE}$ inhibitors derived from nature, are actively searched for in different laboratories worldwide. In this context, the neuroprotective and anti-ageing potentials of essential oils (EOs) are considered to be highly effective and are therefore widely evaluated [50].

In our continuing search for selective $\mathrm{ChE}$ inhibitors from natural sources, we have tested the S. leucantha EO in an in vitro assay (see Experimental). The oil showed high activity against $\mathrm{BuChE}$, with a value of $\mathrm{IC}_{50}=32.60 \pm 5.60 \mu \mathrm{g} / \mathrm{mL}$ (Figure 1), while it was inactive, $\mathrm{IC}_{50}>250 \mu \mathrm{g} / \mathrm{mL}$, against the enzyme AChE. 


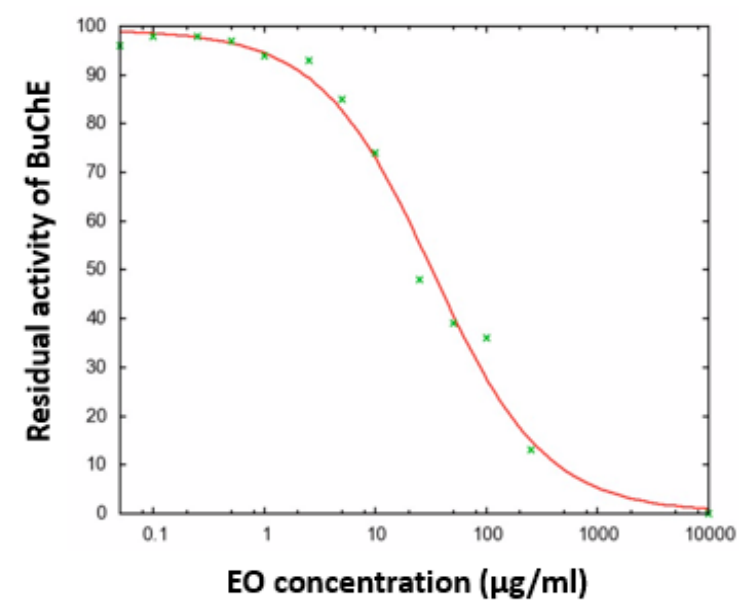

Figure 1. Inhibition activity curve of S. leucantha EO against BuChE.

In comparison with these results, other Salvia species, i.e., S. pichinchensis [17], S. fruticosa, and S. officinalis [51], showed significantly lower BuChE inhibitory activity, with values of $\mathrm{IC}_{50}=50.70 \mu \mathrm{g} / \mathrm{mL}, 150 \mu \mathrm{g} / \mathrm{mL}$ and $140 \mu \mathrm{g} / \mathrm{mL}$, respectively.

\section{Materials and Methods}

\subsection{Collection of Plant Material}

Aerial parts of Salvia leucantha Cav. in full bloom were collected in June 2019 in province of Azuay, Cuenca, Ecuador ( $\left.2^{\circ} 55^{\prime} 05.8^{\prime \prime} \mathrm{S} 7^{\circ} 900^{\prime} 00.9^{\prime \prime} \mathrm{O}\right)$. The plant was identified by the UTPL botanist José Miguel Andrade and a voucher has been deposited in the UTPL herbarium with the code HUTPL14256.

\subsection{Essential Oil Isolation}

The EO of S. leucantha was obtained from the aerial part of the plant (leaves and flowers) by steam distillation for $4 \mathrm{~h}$, using a Clevenger-type equipment. The EO was separated from the aqueous layer, dried over anhydrous $\mathrm{Na}_{2} \mathrm{SO}_{4}$, filtered, and stored in an amber vial at $4{ }^{\circ} \mathrm{C}$ until use. The procedure was performed in triplicate.

\subsection{Physical Properties}

The relative density of the $\mathrm{EO}$ was determined according to the international standard AFNOR NF T75-111 (ISO 279:1998) guidelines. The refractive index was determined in an ABBE refractometer, according to the international standard AFNOR NF 75-112 (ISO 280:1998) procedure. Each analysis was performed in triplicate.

\subsection{Chemical Composition of the Essential Oil}

\subsubsection{Gas Chromatography Coupled to Mass Spectrometry (GC-MS)}

The EO was qualitatively analysed by GC-MS, using an Agilent Technologies Chromatograph $6890 \mathrm{~N}$, coupled to an Agilent mass spectrometer, 5973 Inert series, which operated in electron impact mode at a $70 \mathrm{eV}$ and was controlled by an MSD-ChemStation software.

Two types of chromatographic columns were used for the analysis: a non-polar column DB-5ms ( $5 \%$ phenyl-methylpolysiloxane; $30 \mathrm{~m} \times 0.25 \mathrm{~mm} \times 0.25 \mu \mathrm{m}$ ) and a HP-INNOWax polar column (polyethylene glycol; $30 \mathrm{~m} \times 0.25 \mathrm{~mm} \times 0.25 \mu \mathrm{m}$ ); helium was used as the carrier gas in both analyses (at a constant flow of $1.00 \mathrm{~mL} / \mathrm{min}$ ). The injection system operated in split mode $(40: 1)$ at $220^{\circ} \mathrm{C}$. The GC oven temperature was programmed at $60^{\circ} \mathrm{C}(5 \mathrm{~min})$, then it was increased to $250{ }^{\circ} \mathrm{C}(10 \mathrm{~min})$ at a rate of $3^{\circ} \mathrm{C} / \mathrm{min}$. We injected $1 \mu \mathrm{L}$ of a solution of the $\mathrm{EO}$ in $\mathrm{CH}_{2} \mathrm{Cl}_{2}(1: 100 v / v)$ in each analysis.

The volatile components of the $\mathrm{EO}$ were identified by comparing the linear retention indices (LRI) and the mass spectra with the data reported in the literature. Each LRI was 
calculated according to Van Den Dool and Kratz [27], from a homologous series of $n$-alcanes $\mathrm{C}_{9}-\mathrm{C}_{25}\left(\mathrm{C}_{9}\right.$, BHD purity $99 \%$ and $\mathrm{C}_{10}-\mathrm{C}_{25}$, Fluka purity $\left.99 \%\right)$, which were injected on each of the two columns after the EO, under identical conditions [17].

\subsubsection{Gas Chromatography Coupled to the Flame Ionization Detector (GC-FID)}

Quantitative analysis of the EO was carried out by GC-FID on an Agilent Technologies $6890 \mathrm{~N}$ series gas-chromatograph coupled to a flame ionization detector (FID), using the DB-5ms and HP-INNOWax columns cited before. The analytical gas-chromatographic conditions were similar to those used for the GC-MS analysis. The relative amount (expressed as a percentage) of each compound identified in the EO was calculated by comparing the area of the corresponding peak in the GC-FID chromatogram with the total area of identified peaks (Table 1). No correction factor was applied. Three injections of the EO were performed to determine each average percentage and the standard deviation [17].

\subsection{Enantiomeric Analysis}

The enantioselective analysis of the EO was performed on the GC-MS instrument cited before, using the chiral capillary column MEGA-DEX-DET-Beta (Diethyl tertbutylsilyl- $\beta$ cyclodextrin; $25 \mathrm{~m} \times 0.25 \mathrm{~mm} \times 0.25 \mu \mathrm{m}$ ). The analytical conditions were the same as those used for the qualitative analysis of the oil, except the oven temperature, which was kept at $60{ }^{\circ} \mathrm{C}(5 \mathrm{~min})$, then increased to $220^{\circ} \mathrm{C}(5 \mathrm{~min})$ at a rate of $2{ }^{\circ} \mathrm{C} / \mathrm{min}$. The enantiomeric distribution and enantiomeric excess of each enantiomeric pair were determined by comparison with authentic reference compounds.

\subsection{Inhibition of Cholinesterase ( $A C h E$ and $B u C h E)$}

The inhibitory activity of cholinesterases (ChEs) by the EO was determined by a colorimetric process based on the methodology established by Ellman et al. [52], against acetylcholinesterase (AChE, from Electrophorus electricus, Sigma Aldrich, C3389, St. Louis, $\mathrm{MO}, \mathrm{USA})$ and butyrylcholinesterase (BuChE, from an equine serum, Sigma Aldrich, SRE020, Missouri, USA). The two enzymes catalyze the hydrolysis of choline esters such as acetylthiocholine (ACh) [53]. A phosphate-buffered saline solution (200 $\mu \mathrm{L}, \mathrm{pH} 7.4)$, DTNB or Ellman reagent $(1.5 \mathrm{mM})$ and an EO sample dissolved in DMSO $(1 \% v / v)$ were used for the test. The enzymes AChE and BuChE were separately dissolved in the phosphatebuffered saline solution, using $25 \mathrm{mU} / \mathrm{mL}$ for each test. After 10 min of pre-incubation, acetylthiocholine iodide $(1.5 \mathrm{mM})$ was added to start the reaction. After $30 \mathrm{~min}$ of incubation at $30{ }^{\circ} \mathrm{C}$, the reaction kinetics were read in 96-well microtiter plates by a Varioskan Flash (Thermo Fisher Scientific, Waltham, MA, USA) detection system. Enzymatic activities were calculated for increasing concentrations, from 0.05 to $250 \mu \mathrm{g} / \mathrm{mL}$ (see Figure 1) of the EO dissolved in DMSO. For the assay, false-positive results $(>100 \mu \mathrm{g} / \mathrm{mL})$, due to the possible presence of amines or aldehydes, were excluded [54]. All measurements were performed in triplicate. The $\mathrm{IC}_{50}$ inhibition values were calculated using a nonlinear regression model (GNUPLOT package, www.ic50.tk (accessed on 1 March 2021), www.gnuplot.info (accessed on 1 March 2021)). Donepezil was used as a reference inhibitor [55] for both enzymes, $\mathrm{AChE}\left(\mathrm{IC}_{50}=0.04 \mu \mathrm{g} / \mathrm{mL}\right)$ and BuChE $\left(\mathrm{IC}_{50}=3.6 \mu \mathrm{g} / \mathrm{mL}\right)$.

\section{Conclusions}

The EO steam-distilled from the aerial parts of S. leucantha, collected in Southern Ecuador, contained a high amount of sesquiterpene hydrocarbons. The most abundant components were 6.9-guaiadiene, $(E)$-caryophyllene, bornyl acetate, germacrene $\mathrm{D},(E)$ - $\beta$ farnesene, and bicyclogermacrene. The enantioselective analysis of the oil, performed for the first time, indicated the presence of four non-racemic pairs of enantiomers. Moreover, the EO of $S$. leucantha exhibited an interesting selective inhibitory activity against the enzyme BuChE. The value of $\mathrm{IC}_{50}=32.60 \mu \mathrm{g} / \mathrm{mL}$ is possibly the highest for EOs from Salvia species [51]. The oil can therefore be considered as a source of bioactive phytochemicals and phytotherapeutics for humans due to its potential anti-Alzheimer activity. 
Author Contributions: Conceptualization, C.A.; investigation, G.V. (Gabriela Villalta), M.S., N.B. and C.L.; resources, M.S. and J.C.; writing—original draft preparation, G.V. (Gabriela Villalta); writingreview and editing, C.A. and G.V. (Giovanni Vidari); supervision, C.A. All authors have read and approved the submitted version of the manuscript.

Funding: This research received no external funding.

Institutional Review Board Statement: Not applicable.

Informed Consent Statement: Not applicable.

Acknowledgments: We are grateful to the Universidad Técnica Particular de Loja (UTPL) for supporting this investigation and open access publication.

Conflicts of Interest: The authors declare no conflict of interest.

\section{References}

1. Martínez, M.; Fragous, I.; Garcia, M.; Montiel, O. Géneros de Lamiaceae de México, diversidad y endemismo. Rev. Mex. Biodiv. 2013, 84, 30-86. [CrossRef]

2. Ebani, V.V.; Nardoni, S.; Bertelloni, F.; Giovanelli, S.; Ruffoni, B.; D’Ascenzi, C.; Pistelli, L.; Mancianti, F. Activity of Salvia dolomitica and Salvia somalensis Essential oils against bacteria, molds and yeasts. Molecules 2018, 23, 396. [CrossRef]

3. León, S.; Valencia, R.; Pitman, N.; Endara, L.; Ulloa, C.; Navarrete, H. Libro Rojo de las Plantas Endémicas del Ecuador, 2nd ed.; Herbario QCA, Pontificia Universidad Católica del Ecuador: Quito, Ecuador, 2011; p. 367.

4. Carović, K.; Petek, M.; Grodyca, M.; Paint, J.; Bedekovic, D.; Herak, M.; Satovic, Z. Medicinal plants of the family Lamiaceae as functional foods-A review. Czech. J. Food Sci. 2016, 34, 377-390. [CrossRef]

5. Rojas, L.B.; Visbal, T.; Morillo, M.; de Rojas, Y.C.; Arzola, J.C.; Usubillaga, A. The volatile constituents of Salvia leucantha. Nat. Prod. Commun. 2010, 5, 937-938. [CrossRef] [PubMed]

6. INECOL. Cordón de Jesús. Available online: https://www.inecol.mx/inecol/index.php/es/ct-menu-item-25/planta-del-mes/ 37-planta-del-mes / 602-cordon-de-jesus (accessed on 18 December 2020).

7. Hosoki, T.; Tahara, Y. In vitro propagation of Salvia leucantha Cav. HortScience 1993, 28, 226. [CrossRef]

8. Negi, A.; Javed, M.; Melkani, A.; Dev, V.; Beauchamp, P. Steam volatile terpenoids from Salvia leucantha. J. Essent. Oil Res. 2007, 19, 463-465. [CrossRef]

9. Inderaja, B.; Pradhita, O.; Hanifah, R.; Manurung, R.; Abduh, M. Factors affecting biomass growth and production of essential oil from leaf and flower of Salvia leucantha Cav. J. Essen. Oil Bear. Plants 2018, 21, 1021-1029. [CrossRef]

10. Skała, E.; Rijo, P.; Garcia, C.; Sitarek, P.; Kalemba, D.; Toma, M.; Szemraj, J.; Pytel, D.; Wysokińska, H.; Śliwiński, T. The essential oils of Rhaponticum carthamoides Hairy roots and roots of soil-grown plants: Chemical composition and antimicrobial, anti-inflammatory, and antioxidant activities. Oxid. Med. Cell. Longev. 2016, 2016, 1-10. [CrossRef]

11. Shaaban, H.A.; El-Ghorab, A.H.; Shibamoto, T. Bioactivity of essential oils and their volatile aroma components. J. Essent. Oil Res. 2012, 24, 203-212. [CrossRef]

12. Seow, Y.X.; Yeo, C.R.; Chung, H.L.; Yuk, H.G. Plant essential oils as active antimicrobial agents. Food Sci. Nutr. 2014, 54, 625-644. [CrossRef]

13. Pandey, A.K.; Kumar, P.; Singh, P.; Tripathi, N.N.; Bajpai, V.K. Essential oils: Sources of antimicrobials and food preservatives. Front. Microbiol. 2017, 7, 1-14. [CrossRef]

14. Dos Santos, T.C.; Gomes, T.; Pinto, B.; Camara, A.; Paes, A. Naturally occurring acetylcholinesterase inhibitors and their potential use for Alzheimer's disease therapy. Front. Pharmacol. Res. 2018, 9, 1-14. [CrossRef]

15. Bartorelli, L.; Giraldi, C.; Saccardo, M.; Cammarata, S.; Bottini, G.; Fasanaro, A.; Trequattrini, A. Effects of switching from an AChE inhibitor to a dual AChE- BuChE inhibitor in patients with Alzheimer's disease. Curr. Med. Res. Opin. 2005, 21, 1809-1817. [CrossRef]

16. Adams, R. Identification of Essential Oil Components by Gas Chromatograpy/Mass Spectrometry, 4th ed.; Allured Publishing Corporation: Carol Stream, IL, USA, 2007.

17. Salinas, M.; Bec, N.; Calva, J.; Ramírez, J.; Andrade, J.; Vidari, G.; Larroque, C.; Armijos, C. Chemical composition and anticholinesterase activity of the essential oil from the Ecuadorian plant Salvia pichinchensis Benth. Rec. Nat. Prod. 2020, 14, 276-285. [CrossRef]

18. Sandasi, M.; Kamatou, G.; Viljoen, A. Chemotaxonomic evidence suggests that Eriocephalus tenuifolius is the source of cape chamomile oil and not Eriocephalus punctulatus. Biochem. Syst. Ecol. 2011, 39, 328-338. [CrossRef]

19. Saroglou, V.; Marin, P.D.; Rancic, A.; Veljic, M.; Skaltsa, H. Composition and antimicrobial activity of the essential oil of six Hypericum species from Serbia. Biochem. Syst. Ecol. 2007, 35, 146-152. [CrossRef]

20. Bisio, A.; Ciarallo, G.; Romussi, G.; Fontana, N.; Mascolo, N.; Capasso, R.; Biscardi, D. Chemical composition of essential oils from some Salvia species. Phytother. Res. 1998, 12, S117-S120. [CrossRef]

21. Valarezo, E.; Castillo, A.; Guaya, D.; Morocho, V.; Malagón, O. Chemical composition of essential oils of two species of the Lamiaceae family: Scutellaria volubilis and Lepechinia paniculata from Loja, Ecuador. J. Essent. Oil Res. 2012, 24, 31-37. [CrossRef] 
22. Armijos, C.; Matailo, A.; Bec, N.; Salinas, M.; Aguilar, G.; Solano, N.; Calva, J.; Ludeña, C.; Larroque, C.; Vidari, G. Chemical composition and selective BuChE inhibitory activity of the essential oils from aromatic plants used to prepare the traditional Ecuadorian beverage horchata lojana. J. Ethnopharmacol. 2020, 263, 1-12. [CrossRef] [PubMed]

23. Demirci, B.; Başer, K.; Yildiz, B.; Bahçecioğlu, Z. Composition of the essential oils of six endemic Salvia ssp. from Turkey. Flavour Fragr. J. 2003, 18, 116-121. [CrossRef]

24. Paolini, J.; Muselli, A.; François, A.; Bighelli, A.; Casanova, J.; Costa, J. Thymol derivatives from essential oil of Doronicum corsicum L. Flavour Fragr. J. 2007, 22, 479-487. [CrossRef]

25. Amiri, N.; Yadegari, M.; Hamedi, B. Essential oil composition of Cirsium arvense L. produced in different climate and soil properties. Rec. Nat. Prod. 2018, 12, 251-262. [CrossRef]

26. Saïdana, D.; Mahjoub, S.; Boussaada, O.; Chriaa, J.; Mahjoub, M.; Chéraif, I.; Daami, M.; Mighri, Z.; Helal, A. Antibacterial and antifungal activities of the essential oils of two saltcedar species from Tunisia. J. Am. Oil Chem. Soc. 2008, 85, 817-826. [CrossRef]

27. Van del Dool, H.; Kratz, P. A generalization of the retention index system including linear temperature programmed gas-liquid partition chromatography. J. Chromatogr. A 1963, 11, 463-471. [CrossRef]

28. Upadhyaya, K.; Dixit, V.; Padalia, R.; Mathela, C. Terpenoid composition and antioxidant activity of essential oil from leaves of Salvia leucantha Cav. J. Essent. Oil-Bear Plants 2009, 12, 551-556. [CrossRef]

29. Ali, A.; Tabanca, N.; Demirci, B.; Blythe, E.; Ali, Z.; Baser, K.; Khan, I. Chemical composition and biological activity of four Salvia essential oils and individual compounds against two species of mosquitoes. J. Agric. Food Chem. 2015, 63, 447-456. [CrossRef] [PubMed]

30. Castrillón, W.; Matulevich, J.; Rodríguez, J.; Silva, D. Composición química del aceite esencial de flores de Salvia leucantha Cav. (Lamiaceae). Rev. Fac. Cienc. Básicas 2019, 15, 41-47. [CrossRef]

31. Oliveira, M.; Brugnera, D.; Cardoso, M.; Guimarães, L.; Piccoli, R. Rendimento, composição química e atividade antilisterial de óleos essenciais de espécies de Cymbopogon. Rev. Bras. Plantas Med. 2011, 13, 8-16. [CrossRef]

32. Al-Bayati, F.A. Synergistic antibacterial activity between Thymus vulgaris and Pimpinella anisum essential oils and methanol extracts. J. Ethnopharmacol. 2008, 116, 403-406. [CrossRef]

33. Basha, R.H.; Sankaranarayanan, C. $\beta$-Caryophyllene, a natural sesquiterpene lactone attenuates hyperglycemia mediated oxidative and inflammatory stress in experimental diabetic rats. Chem. Biol. Interact. 2016, 245, 50-58. [CrossRef]

34. Hernandez-Leon, A.; González-Trujano, M.E.; Narváez-González, F.; Pérez-Ortega, G.; Rivero-Cruz, F.; Aguilar, M.I. Role of $\beta$-caryophyllene in the antinociceptive and anti-Inflammatory effects of Tagetes lucida Cav. essential oil. Molecules 2020, $25,675$. [CrossRef] [PubMed]

35. Fidyt, K.; Fiedorowicz, A.; Strzadala, L.; Szumny, A. $\beta$-Caryophyllene and $\beta$-caryophyllene oxide-natural compounds of anticancer and analgesic properties. Cancer Med. 2016, 5, 3007-3017. [CrossRef] [PubMed]

36. Prosser, I.; Altug, I.G.; Phillips, A.L.; König, W.A.; Bouwmeester, H.J.; Beale, M.H. Enantiospecific (+)- and (-)-germacrene D synthases, cloned from goldenrod, reveal a functionally active variant of the universal isoprenoid-biosynthesis aspartate-rich motif. Arch. Biochem. Biophys. 2004, 432, 136-144. [CrossRef] [PubMed]

37. Schepetkin, I.A.; Özek, G.; Özek, T.; Kirpotina, L.N.; Khlebnikov, A.I.; Quinn, M.T. Chemical composition and immunomodulatory activity of Hypericum perforatum essential oils. Biomolecules 2020, 10, 916. [CrossRef]

38. Crock, J.; Wildung, M.; Croteau, R. Isolation and bacterial expression of a sesquiterpene synthase cDNA clone from peppermint (Mentha $x$ piperita, L.) that produces the aphid alarm pheromone (E)- $\beta$-farnesene. Proc. Natl. Acad. Sci. USA 1997, 94, 12833-12838. [CrossRef]

39. Sun, Y.; Qiao, H.; Ling, Y.; Yang, S.; Rui, C.; Pelosi, P.; Yang, X. New analogues of (E)- $\beta$-farnesene with insecticidal activity and binding affinity to aphid odorant-binding proteins. J. Agric. Food Chem. 2011, 59, 2456-2461. [CrossRef]

40. Grecco, S.; Martins, E.G.; Girola, N.; de Figueiredo, C.R.; Matsuo, A.L.; Soares, M.G.; Bertoldo, B.; Sartorelli, P.; Lago, J.H. Chemical composition and in vitro cytotoxic effects of the essential oil from Nectandra leucantha leaves. Pharm. Biol. 2015, 53, 133-137. [CrossRef]

41. Giuliani, C.; Pieraccini, G.; Santilli, C.; Tani, C.; Bottoni, M.; Schiff, S.; Fico, G.; Papini, A.; Falsini, S. Anatomical investigation and GC/MS analysis of 'Coco de Mer', Lodoicea maldivica (Arecaceae). Chem. Biodivers. 2020, 17, 1-23. [CrossRef]

42. Kim, S.H.; Lee, S.Y.; Hong, C.Y.; Gwak, K.S.; Park, M.J.; Smith, D.; Choi, I.G. Whitening and antioxidant activities of bornyl acetate and nezukol fractionated from Cryptomeria japonica essential oil. Int. J. Cosmet. Sci. 2013, 35, 484-490. [CrossRef]

43. Yang, H.; Zhao, R.; Chen, H.; Jia, P.; Bao, L.; Tang, H. Bornyl acetate has an anti-inflammatory effect in human chondrocytes via induction of IL-11. IUBMB Life 2014, 66, 854-859. [CrossRef]

44. Chen, N.; Sun, G.; Yuan, X.; Hou, J.; Wu, Q.; Soromou, L.W.; Feng, H. Inhibition of lung inflammatory responses by bornyl acetate is correlated with regulation of myeloperoxidase activity. J. Surg. Res. 2014, 186, 436-445. [CrossRef]

45. Feng, Y.X.; Wang, Y.; Chen, Z.Y.; Guo, S.S.; You, C.X.; Du, S.S. Efficacy of bornyl acetate and camphene from Valeriana officinalis essential oil against two storage insects. Environ. Sci. Pollut. Res. Int. 2019, 26, 16157-16165. [CrossRef] [PubMed]

46. Matailo, A.; Bec, N.; Calva, J.; Ramírez, J.; Andrade, J.M.; Larroque, C.; Vidari, G.; Armijos, C. Selective BuChE inhibitory activity, chemical composition, and enantiomer content of the volatile oil from the Ecuadorian plant Clinopodium brownei. Rev. Bras. Farmacogn. 2019, 29, 749-750. [CrossRef]

47. Zeb, A.; Hameed, A.; Khan, L.; Khan, I.; Dalvandi, K.; Choudhary, M.I.; Basha, F.Z. Quinoxaline derivatives: Novel and selective butyrylcholinesterase inhibitors. Med. Chem. 2014, 10, 724-729. [CrossRef] 
48. Greig, N.H.; Utsuki, T.; Yu, Q.; Zhu, X.; Holloway, H.W.; Perry, T.; Lee, B.; Ingram, D.K.; Lahiri, D.K. A new therapeutic target in Alzheimer's disease treatment: Attention to butyrylcholinesterase. Curr. Med. Res. Opin. 2001, 17, 159-165. [CrossRef]

49. Ayaz, M.; Junaid, M.; Ullah, F.; Sadiq, A.; Khan, M.A.; Ahmad, W.; Shah, M.R.; Imran, M.; Ahmad, S. Comparative chemical profiling, cholinesterase inhibitions and anti-radicals properties of essential oils from Polygonum Hydropiper L: A preliminary anti-Alzheimer's study. Lipids Health Dis. 2015, 14, 141-152. [CrossRef]

50. Rashed, A.A.; Rahman, A.Z.A.; Rathi, D.N.G. Essential oils as a potential neuroprotective remedy for age-related neurodegenerative diseases: A review. Molecules 2021, 26, 1107. [CrossRef] [PubMed]

51. Savelev, S.U.; Okello, E.J.; Perry, E.K. Butyryl- and acetyl-cholinesterase inhibitory activities in essential oils of Salvia species and their constituents. Phytother. Res. 2004, 18, 315-324. [CrossRef] [PubMed]

52. Ellman, G.L.; Courtney, K.; Andres, V.; Featherstone, R.M. A new and rapid colorimetric determination of acetylcholinesterase activity. Biochem. Pharmacol. 1961, 7, 88-95. [CrossRef]

53. Bosak, A.; Ramić, A.; Šmidlehner, T.; Hrenar, T.; Primožič, I.; Kovarik, Z. Design evaluation of selective butyrylcholinesterase inhibitors based on Cinchona alkaloid scaffold. PLoS ONE 2018, 13, 1-18. [CrossRef]

54. Rhee, I.K.; Van Rijn, R.M.; Verpoorte, R. Qualitative determination of false-positive effects in the acetylcholinesterase assay using thin layer chromatography. Phytochem. Anal. 2003, 14, 127-131. [CrossRef] [PubMed]

55. McGleenon, B.; Dynan, K.; Passmore, A. Acetylcholinesterase inhibitors and Alzheimer's disease. Br. J. Clin. Pharmacol. 1999, 48, 471-480. [CrossRef] [PubMed] 